\title{
African Slave Labour, the Atlantic Trading Area and the Industrial Revolution to 1850.
}

\author{
DR Danazumi Sharwa Bukar \\ Solomon Lar University Bokkos Plateau state Nigeria
}

\begin{abstract}
The rise of the industrial revolution was a major turning point in World history. This paper argues that the context of the political economy that birthed the revolution flung far beyond the European continent where the levers of the revolution rested. The search for the critical factors that led to this most fundamental of all revolutions that pushed human society forward up to 1850, has been a subject of considerable controversy. The argument in this paper is that Africans, in forced Diaspora, provided slave labor in the context of the Atlantic trading area popularly described as a triangle that connected the continents of Africa, Europe and America. It was this trade triangle that provided the critical mass for this revolution to explode. The internationalization of trade flows from the $15^{\text {th }}$ century, the rise of the slave trade and the development of the mineral and plantation economy on the American continent all played out as a process over the centuries leading to the revolution. This was the triangle the globalizing World produced which this paper argues that what Africa contributed to it acted as the most critical, if the fact that it is labor, in its manual or mechanical form, that pushes any economic productive system, is accepted as incontrovertible. African slave labour oiled the entire economy of the trading area providing the multiplier effects that propelled it to produce the revolution. It was the staying power of the economy as the base of the triangle. With the revolution, emphasis began to shift from manual to mechanical labour as staying power, this, not until the latter had begotten the former, African slave labour remained the harbinger of the industrial revolution and society. ${ }^{{ }^{2}}$
\end{abstract}

Key words: Slave Labour, Atlantic trade, Industrial Revolution

\section{Introduction}

This paper surveys the rise of industrial capitalism in Western Europe up to the middle of the $19^{\text {th }} \mathrm{c}$ with a special focus on the role the Atlantic based mercantilist economy that emerged over one century before it, played.

\section{The Atlantic Trading Area}

The evolution of the Atlantic trading area began with the Portuguese and Spanish 15thc voyages, which, as we all know, forced the two continents of Africa and America into unequal economic relationship with Europe. ${ }^{1}$

The Western African Atlantic coast from Senegal to Namibia was by the 17thc, dotted with European settlements that brought the entire coastline under their control. From these fort-settlements Europe got to monitor and control even the hinterland of the continent to obtain slaves and sell their goods. As we seek to demonstrate in this paper, this part of the Atlantic trading area and industrial capitalism ultimately.

\section{The Americas}

The colonization and incorporation of the American continent into the Atlantic trading area began early in the $16^{\text {th }} \mathrm{c}$, with Portugal and Spain as the leading colonizing powers. Eastern Brazil and Mexico were, for example annexed and incorporated into the area by the turn of the century. Jamaica and Barbados followed by 1650, when they were affectively occupied and colonized by England.

The Dutch, French, Swedes and the English, had by the $16^{\text {th }} \mathrm{c}$ and $17^{\text {th }} \mathrm{c}$, established settlements along the North American seaboard from their positions along the seaboards, these colonizers penetrated and incorporated the American mainland into the trading area. The English Virginia company, for example, established settlements in Jamestown in 1607 and the pilgrims in Playmonth, between 1620 and 1621. By the 1640 s, all these powers had also colonized much of the American continent, by anihalating its hitherto existing people developed plantations, and exploited its enormous mineral resources, using African labour.

\section{Europe}

Europe controlled and dominated this production and trading systems, as is *-obvious from the foregoing discussion. She imposed a division of labour of her choice on the continents of the Atlantic world, thus, internationalizing the production and distribution of goods to her advantage. ${ }^{2}$ Thus Europe, in the division 
of her creation, dominated trade, controlled finance and monopolized production. The American continent especially the Caribbean and South America, supplied industrial crops and mineral resources, ${ }^{3}$ while the benighted continent of Africa shouldered the responsibility of supplying slave lobour ${ }^{4}$.

Utilizing the enormous outlay of African slave labour, the exploitation of the rich and vast natural resources of the American continent was effected, to make the Atlantic trading area functional.

\section{The Growth Of Intra-European Trade}

With Europe in a firm control of the technology and finances that drove the activities of the trading area, her economic expansion could not be mistaken, especially, between the $17^{\text {th }}$ and $18^{\text {th }}$ centuries. The phenomenal growth of intra-European trade in this period was captured thus by J.E Inikori:

"The growth of trade between the European countries in this period depended greatly on the re-export of American products from one

Country to another and the export of Europeans goods from one country to another for onward transshipment to the Americas"

The Methuen treaty of 1650 boosted and consolidated trade between Portugal and Britain. Portugal in the treaty agreed to buy and re-export textile goods from Britain. The striking gold finds in her Brazilian possessions enabled Portugal to achieve an unprecedented increase her purchasing power. The annual production of gold by Portugal between 1691 and 1700 was put at an average of 1,500 $\mathrm{kg}$ and 2,750 kg between 1760 and 172. The annual average jumped to 14,600 kg between 1760 and 1774. Portugals'trade with France, Germany and Holland were similarly based on the force of her gold finds that grew by leaps and bounds between 1691 and 1774 .

Lisbon became one of the wealthiest cities in Europe with increased purchasing power of its merchants making it possible for them to give employment. But with the low level of industrial development in Portugal, and, the prohibition of manufacturing in the colonies, the Brazilian gold finds increased industrial production only in Britain, France and Germany.

The English shipping industry, much of which was engaged in the Atlantic area, expanded into the Baltic region with which trade in large quantities of timber, iron, flax and hemp, developed. The imports from this region further boosted the English shipping industry. Her metallurgical industries also gained from the trade with the region.

Trade relations between England and Germany were similarly based on the fortunes of the Atlantic trade. England for example, imported linen and linen yarn form Germany that was not yet directly engaged in the colonial and slave trade of the time. In exchange, Germany obtained re-exported sugar from Britain and France, as a result of which Hamburg became an important sugar refining city ${ }^{6}$.

Spain, one of the pioneering colonizing powers exported wool to England while importing her reexported fish from New found land ${ }^{7}$ and most importantly the new draperies, used in the Spanish colonial and slave trade.

Holland, similarly, supplied textiles, cowries and almost all metal requirements of the slave traders of Nantes in France, in the $17^{\text {th }}$ and $18^{\text {th }}$ centuries. The Dutch obtained large quantities of sugar and other colonial based products in exchange.

A further examination of this fact shows that Portugal also re-exported large quantities of Brazilian dyewood into the Mediterranean, the North Sea and the Baltic region from where they were passed into the continental cloth industry of the $17^{\text {th }}$ century. Portugal in return got ships for her trading activities from Holland, Germany and France.

The commodity composition of English overseas trade by 1600 consisted of between 80 and 90 percent woolen products. However, by 1701, one century later, the composition had been significantly altered by the reexport of goods obtained through the Atlantic trading area accounting for up to one third of total exports.

The multiplier effect of the slave trade on the European economy, in this period was quite enormous. Apart from its crucial generative roles in the workings of the Atlantic trading system, it touched virtually all sectors of the European economy. Businesses organized around the slave trade became the most successful. Similarly it was the more developed capitalist economies in Europe that dominated the macro levels of the trading system. England, for example, controlled about half of all the slaves involved in the trading system. It re-exported a greater number of the slaves than she actually kept. England is known to have resold about 2/3 of her slaves to non English colonies. ${ }^{10}$

Because of the heavy dependence of the European economy on the Atlantic trading system, Francois Crouzet, concluded that the European economy in the $18^{\text {th }}$ century was outward looking; ocean oriented and geared to seaborne trade and American markets. ${ }^{11}$ He should have added "and African markets".

This assessment of the European economy in the $18^{\text {th }}$ century shows how its motive force was located in the Atlantic productive and distributive economic system as driven by African slave labour. We cannot exhaust this evidence of African slave labour playing a primary and central role in the Atlantic trading system. 
For apart from this labour making the production of industrial crops and mineral resources in the American continent possible, it heavily subsidized industrial production in Europe. This triggered off both intra and intercontinental trading activities on a scale that was never before precendented in the history of Europe. Goods abounded to force down prices, especially because of the lowered cost of production on account of the use of slave labour. Thus, sugar, tobacco, coffee and tea, in raw form, flooded European markets form the American continent to become common foods on the tables of average European families.

\section{The Rise Of Industrial Capitalism}

The rise of industrial capitalism was heavily anchored on the dynamics of the Atlantic trade. The technology of industrial production which entailed the invention and fabrication ${ }^{12}$ of machine tools and machine making machine tools all driven by engine power did not just fall from the skies. It was only made possible within the womb of the Atlantic trading system in two major ways. In the first place, the European economies benefitted tremendously from their responses to the multiplier effects generated by the roles they played in the Atlantic trading system. What else should we expect from a continent which acted as the centre for manufacturing, finance and transportation? In the second place, the heavy capital requirements needed for investment into the invention and fabrications of machine and machine making tools was met from the lavish profits and fortunes gotten from the trading system.

The Atlantic trading system opened up the economies of Western Europe affording them boom conditions that transformed very crucial sectors of production. It facilitated institutional and structural changes that occasioned a tremendous expansion of the industrial base of the economy, apart from generating new ones. This, as already hinted, was in response to the practical demands of buying and shipping slaves, on the one hand, and the production and distribution of commodities associated with it, on the other.

One of the first industries to respond in this way, following stupendous increases in the volume of intra-European and oversea trade, was the ship building industry. Port cities developed very large ship and dock yards for feeding the growing trade of the continent with the rest of the world. Cities like London, Bristol, Liverpool in England and Nantes, Bordeaux and others in France, developed large ship and dock yards including other German and Dutch port cities. Apart from improving on the sizes and speed of ships to meet growing demands of an expanding global trade, new devices of improving their quality were also introduced. These included copper sheathing which was developed to prevent the rotting away of ship bellies on account of constantly being on the warm waters of the Atlantic Ocean. Research to establish the extent of the British ship building industry, undisputed leader of the global seaborne trade, revealed that British Slave merchants between 1750 and 1807 averagely spent up to $2,625,929$ pounds per decade as expenditure on their ships. ${ }^{13}$

The European textiles industry made similar responses. Massive expansion in the industry to meet the growing demands of slave traders and the colonial trade of the new world was very evident. The new draperies, fabricated from wool for people from the warm climates of Africa and America, was specifically developed as a fresh product to meet the demands of these traders. Again to demonstrate the dominant role Britain played in the trading system, the draperies she exported in 1772 accounted for $72 \%$ of all draperies exported in that year. The enormous demand for draperies by Portugal as a result of the exploitation of Brazilian gold and enhanced purchasing power including that of Brazil tremendously boosted the English woolen industry.

Similarly, the Linen industries in France, Germany and Holland expanded rapidly because of the Atlantic trade which widened its European market and created new ones overseas.

Metallurgical industries similarly expanded like the textile and ship building industries, within the ambit of the demands of the Atlantic trade especially the copper, iron and brass industries of Bristol and south Wales. $^{14}$

Germany, which we noted as only being indirectly linked to the Atlantic trade, also witnessed a tremendous expansion of her Metallurgical industries as she supplied such hard wares as arms and cutleries to her neighbours that were directly participating in the trade. This strongly accounted for the rapid development of the Rhineland and Saxony as the industrial nucleus of the country.

Ralph David summarized the case of Britain by arguing that:

"the process of industrialization in England from the second quarter of the 18thc was to an important extend a response to colonial demand for clocks, saddles, handkerchiefs, buttons, cordage." 15

In a very general way, the demand for fetters, chains and padlocks to fasten the millions of African slaves transshipped to the new world, stimulated industrial growth in Europe, in no small measure. The arms industry benefited from the slave and colonial trade of this period, in the same way. Birmingham in England, Etienne in France were the greatest beneficiaries of the expansion in the demand for arms.

Besides, the trading system created entirely new industries and production lines in Europe to feed growing market demands in America, Africa and Europe itself. The cotton textile industry is the best example of this because it depended entirely on imported cotton lint from America, the Levant and southern Italy. 
Manchester which developed the best cotton textiles industries, to meet demands of the domestic market and slave traders in the $18^{\text {th }} \mathrm{c}$, and Lancashire which exported 14,000 pounds worth of textiles goods in 1739 and over eight times of this in 1759, are notable in this regard. Cotton textile industries also developed in France. By 1733, Nantes, one of the country's major centres of production was, for example, making half a million livres worth of cotton textiles a year with a work force of 1000 men. ${ }^{16}$

The fact that industrial revolution was first adapted in the textile industry, demonstrates the role of external demand in calling forth technical innovations and inventions. England, where the revolution started, heavily depended on the Atlantic trading area for the sales of her textiles products as already noted. For example, between 1750 and 1776, when large scale technical and mechanical changes were taking place in the English economy, 30 to $50 \%$ of all her cotton textile exports were to the west coast of Africa. The great potentials for adaptation to mass production explains why the textile industry was the first to respond to the revolution.

Numerous food processing industries also sprang up in response to the Atlantic trading system because Europe through it obtained industrial crops such as sugar, tobacco, and coffee. Sugar refining developed in England, France, Germany and Holland based on imported raw sugar form the new world. Hamburg, interestingly, became one of the largest sugar refining cities in Europe, in the $18^{\text {thc }}$ working with imported raw sugar from Britain and France. ${ }^{17}$

Rum distillation, tobacco and tea processing and chocolate manufacture, are all food processing industries that developed due to the availability of sugar, tea and tobacco, in raw form, from the America continent.

Structural and institutional changes also occurred in this period in keeping with the overall economic transformation of Europe. The first institutional change to be noted was the growth of capitalist relations of production and the capitalist market. This process of change was aided by the flow of gold bullion from Africa and later on, from the new world, especially the Portuguese and Spanish colonies. The growth of money based exchange, that is, the money market economy, was greatly facilitated by the availability of gold from the above named sources.

Generally, the massive flow of bullion from Africa and the new world, greatly affected the availability of funds, which not only forced down interest rates, but also raised the levels of borrowing in the industrializing economies of Western Europe countries. Borrowing from financial institutions in London, Amsterdam and Paris increased tremendously, thereby boosting business across the continent.

As already amply alluded to, the financial control of the Atlantic trading system was by Western European countries. They came to ultimately control the flow of gold bullion from the new world (especially from Brazil in the $18^{\text {th }} \mathrm{c}$ ) most of the gold producing areas, on them, as already noted. Portugal, for example, paid England an average of one million pounds gold bullion between 1756 and 1760, as trade balance. ${ }^{18}$ France, Germany and Holland also similarly obtained such payments for their manufactures. This made Western Europe the financial hub of the $18^{\text {th }} \mathrm{c}$.

It is quite interesting to note that it was in this context that the banking industry developed as a strong medium for lending money to manufacturers, traders and many other categories of investors to expand their businesses. Slave traders were an interesting example, in this regard. With a long time before profit began to flow and the huge investments needed to start off in business made them the greatest potential borrowers in the expanding West European economies. Thus slave traders, realizing the great demand for capital in their business, set up banks to provide for this demand. A good example of this was the case of David and Alexander Barclays who were successful slaves traders that used the profits they accumulated in the process of buying and selling slaves to float the popularly known Barclays Bank. ${ }^{19}$ Lloyds also sprang from a small coffee house in London, to one of the world's largest banking and insurance house, set up with huge profits made by slave traders. ${ }^{20}$

In a very fundamental way, the European banking industry was largely made up of merchant capital generated through the Atlantic trading system. For example, the most prominent share holders of the very first banks in Bristol were merchants. Also, of the 14 ranking of any standing in the sprawling English fort city of Liverpool, 10 spring from merchant house. French and Dutch traders, similarly, became prominent bankers in Paris and Amsterdam respectively. In fact, a French slave trader, Guillaume Grou, at one time declared himself worth one million livres. At his death in 1774, his fortunes were estimated to be as much as 4,430,000 livres. ${ }^{21}$

The insurance industry also sprouted under similar conditions, in the womb of the Atlantic trading system. The risks and hazards of an international and maritime based trading system were the prime movers in the growth of the insurance industry. Maritime insurance developed largely because of the high risks involved in the slave trade such as the frightful mortality rates among the slaves.

The discount market also originated mainly as a business adjunct to the Atlantic trade. In fact, it all started by discounting bills issued to slave traders. Banks were even established in places like Lancashire with the express purpose of making profits from the discount market of especially the slave market. Far reaching structural changes, as we hinted, also occurred as a result of the enormous expansion of the Atlantic trading 
systems. These changes included the growth of towns, Port facilities and transportation systems; which were all very important pre conditions of the industrial revolution.

Liverpool and Bristol were all Port cities whose growth was markedly associated with foreign trade. Manchester as an industrial city grew largely because of her links with Bristol, one of the leading Port cities of the Atlantic trade. Boudreaux and Nantes in France, Amsterdam in Holland and Hamburg in Germany, were all industrial cities growing largely on the fortunes of the Atlantic trade.

Wharve, coffee house and wetdocks, very important, port facilities developed in theport cities in response to the demands of foreing trade. Being the nerve centres of the industrial revolution the rapid growth of these cities in this context, is very instructive.

The involvement of merchants and businesses associated with the Atlantic trade in the development of urban infrastructure such as roads and canals was visible. They invested huge amounts in this respect because both roads and canals made it possible for merchants to move their goods fast and cheaply. Such investment in roads, canals and bridge construction, in England around the 1750s averaged about 3.5million pounds, every year. The turn-pike company, in this regard, built about one sixth of all roads in England between 1750 and 1816.

The economic transformation brought about by the dynamics of the Atlantic based production and distribution system, described as accumulation on a World scale, immensely contributed to creating the primary conditions for the industrial revolution. In this final section of the paper, we shall examine how profits made from the Atlantic trade contributed to financing the inventions and fabrications of machine and machine tools. The huge profits made by European countries from the Atlantic trade cannot be over emphasized. Walter Rodney quoted Bishop Manry, who was arguing against ending the slave trade and freeing the French slaves colonies in 1791, as saying that although France was making over 200 million livres a year from the colonies, ${ }^{22}$ it was not known. Thus the huge monies siphoned from Africa and the colonies in North and South America immensely aided the inventions and innovations of the $18^{\text {th }}$ and $19^{\text {th }}$ centuries that led to the rise of industrial capitalism in Western Europe. It is, for example, a known fact that the famous invention and fabrication of the steam engine, which sparked off the actual process of the industrial revolution, by James Watt, was directly financed by merchants involved in the West Indian slave trade. ${ }^{23}$ When applied to the textile, mining and shipping industries and the locomotives, the steam engine was automatically the precursor to the first industrial revolution wherein lies the crucial import of the of the Atlantic trade.

History as we know occurs within the context of our daily doings to meet the basic need of reproducing life and the means of continuously sustaining it. When Europe brought the Atlantic world to act together to birth the Atlantic trading system, the overall result was the industrial revolution. The inventions heavily protected by patent Laws, only came in the context an expanding demand for goods. Thus merchants confronting a yawning global market had no choice but patronize and in many instances finance the inventions to demonstrate the fact that these inventions were actually called forth by an increasing demand for the mass production of goods to be channeled into an expanding market, at home and abroad.

We must therefore, emphasize at this juncture, the fact that the application of the inventions to economic use, was strictly on the basis of the profit motive of capitalist business men bent on employing large scale production techniques to retain and expand the market for their goods. This was why James Watt was patronized.

Once this was achieved, these industries expanded rapidly. The English cotton industry, for example, increased its total production from one million pounds worth of goods in 1785 to 31 million pounds in 1830 .

Therefore, we will say in conclusion that, Britain led the industrial revolution because she became the dominant mercantilist country during the period under study. She surpassed the Dutch in the control of the shipping industry. London, as we pointed out, overtook Amsterdam, in the $18^{\text {th }} \mathrm{c}$, as Europe's financial centre. Furthermore, she inherited many of the former French colonies she controlled directly and indirectly. Britain also became the biggest re-exporter of goods associated with the Atlantic trading system.

These advantages in addition to the development of capitalist agriculture earlier than the other European countries, gave Britain a sounder economic base to lead them.

After the industrial take off in Britain by the middle of the $19^{\text {th }} \mathrm{c}$, massive technology transfers into especially, France, Germany and Holland followed. The first industries set up in Germany were mostly in partnerships with companies and businesses with long studying connections with the Atlantic trade.

\section{Conclusion}

The crucial question that this paper has sought to answer is, whether or not the industrial revolution would have occurred, at the time it did, without the Atlantic trading system that developed some centuries before it. We tried to show that it would not have. For as we demonstrated, the initial capital, the goods, the markets and technology on the basis of which the revolution occurred, were all the products of an international economic system spattered across the three continents of Africa, America and Europe. Asia of course made 
contributions which fall outside the context of this paper. The revolution was, therefore, not an exclusive English, or, even European affair, but a globalised one and that all these hang on the slave trade and labour.

\section{Endnotes}

1. Eric Williams Slavery and Capitalism

2. Asia and the Levant are not mentioned here as they do not form part of the Atlantic trading system.

3. Europe achieved this position because of technological advance over the other peoples of the Atlantic. A good example is the manufacturing and use of guns and also superior ship building and navigation.

4. Manufacture was prohibited in the American colonies which clearly show the imposition of a specific role to be played by the colonies.

5. J.E Inikori in his paper, "The African slave trade and the Atlantic economies 1451-1870, in the book, "The African slave Trade from the $15^{\text {th }}$ to the $19^{\text {th }}$ century. The general history of Africa Studies and Document \& Unesco. (Paris 1979) shows in page 79 how for Britain to ensure that Africa provided a regular supply of slaves required for the exploitation of American resources had to discourage the development of the African economy along other lines other than supplying slaves. He shows how the attempts by the Royal African Company to promote the cultivation of sugarcane, tobacco, cotton and indigo in the Gold Coast in 1703 led to the introduction of a bill in the parliament prohibiting it. This also shows the imposition of a specific role for this region.

6. Ibid pg 66

7. Walter Rodney_How Europe Underdeveloped Africa (Howard University Press Washington D.C. 1974.) pg 86.

8. W.E Minchinton (ed) The Growth of English Overseas Trade in the $17^{\text {th }}$ and $18^{\text {th }}$ centuries. (Methuen to Co. Ltd. London 1969) pg 20.

9. Ibid pg 18.

10. J.E Inikori Market and the profits of the British Africa trade in the Late $18^{\text {th }}$ century. Journal of Economic History, vol.XLI No. 4 (Dec. 1981) pg. 774-775.

11. J.E Inikori International trade and the $18^{\text {th }}$ century Industrialization process in England. An Essay in Criticism. (Department of History A.B.U Zaria post Graduate Seminar Paper 25/11/1978) pg. 9

12. Francois Crouzet: Wars, blockade and Economic Change in Europe 1792-1815 Journal of economic History Vol. XXIV No. 4 (1964) pg. 569. Again it should be noted that this discussion left out the Far East, the Levant and India which also contributed to the volume and structure of the international trade we are considering. For Britain the East India trade accounted for about 13\% of the increase in her domestic exports between 1700 and 1775. We should also not forget the Dutch and French East India Companies that were making substantial gains. It is a known fact that during the blockade of the Napoleonic wars 1792 to 1815 France and her allies largely depended on the Levant for cotton supplies that fed their cotton textile industries, see Francois Crouzet op.Cit pg. 578

13. Invention means making a piece of machine for the first time while innovation means the applications of such a machine to the actual process of production.

14. J.E Inikori: Slave trade and the Atlantic Economics, Op.Cit. pg 60.

15. W.E Minchinton (ed) Op.Cit. pg 47.

16. Ralph Davies. English Foreign Trade 1700-1774 an article in, The Growth of English overseas trade in the $17^{\text {th }}$ and $18^{\text {th }}$ centuries; edited by W.E Michintn Ibid pg. 106.

17. Pierre H. Boulle, Slave Trade commercial organization and Industrial Growth in The $18^{\text {th }}$ century Nantes: Journal Reune Francaise D'Histoire D'outre-Mer (1972) pg. 94

18. Walter Rodney, Op.Cit, pg. 86.

19. H.E.S Fisher: Anglo-Portuguese trade 1700-1720, an article in "The Growth of English overseas trade: W.E Minchinton (ed) Op.Cit. pg. 148.

20. Walter Rodney, Op.Cit, pg. 85.

21. Ibid, pg. 85.

22. Pierre H. Boulle, op.cit, pg. 93.

23. Walter Rodney, Op.Cit, pg. 75.

24. Ibid, pg. 85 . 


\section{Bibliography}

[1] J.E Inikori: The African Slave Trade and the Atlantic economics 1451-1870. An article in -The African Slave Trade from the 15 to the $19^{\text {th }}$ centuries. The General history of Africa Studies and documents and Unesco (Paris 1997)

[2] Walter Rodney, How Europe Underdeveloped Africa. (Howard University press Washington D.C1974).

[3] W.E Minchinton (ed). The growth of English Overseas trade in the $17^{\text {th }}$ and $18^{\text {th }}$ centuries. (Menthen \& Co. Ltd. London 1969)

[4] J.E Inikori, Market structure and the profits of the British Africa trade in the $18^{\text {th }}$ century, The Journal of economic History Vol.XLI No. 4 (Dec 1982)

[5] J.E Inikori, International trade and the $18^{\text {th }}$ century industrialization process in England. An essay in criticism (Department of History A.B.U Zaria Post-Graduate seminar paper 25/11/1978)

[6] Francois Crouzet, Wars, blockade and economic change in Europe 1792-1815, Journal of Economic History VoL.XXIV No. 4.(1964).

[7] Pierre H. Boulle, Slave trade, Commercial organization and industrial growth in $18^{\text {th }}$ century Nantes. Reune Francais D'Histoire Obitre-Mer (1972)

[8] J.E Inikori, West Africa's sea born trade 1750-1850, volume structure and Implication: paper presented at the symposium on the qualification and structure of the import and export Trade of Africa in the $19^{\text {th }}$ century. Held at St. Ausgustin (near Bonn). The Federal Republic of Germany (Januanry 1983). 